\title{
THE INFLUENCE OF LIQUIDITY AND PROFITABILITY ON THE BANKING SECTOR PERFORMANCES - THE EXAMPLE OF SERBIA
}

\author{
VESIC Tamara ${ }^{1}$, GAVRILOVIC Milan ${ }^{2}$, PETRONIJEVIC Jovan ${ }^{3}$ \\ 1 Faculty of Business Economics and Entrepreneurship, Belgrade (SERBIA) \\ 2 Faculty of Business Economics and Entrepreneurship, Belgrade (SERBIA) \\ 3 Faculty of Business Economics and Entrepreneurship, Belgrade (SERBIA) \\ E-mails: tamara.vesic@vspep.edu.rs,sagatagm@gmail.com, jovanpetronijevic985@gmail.com
}

\begin{abstract}
As our country has been opening itself more to foreign capital, foreign banks have brought their paradigm of efficient business methods in the banking system of the Republic of Serbia. This paper shows the seven-year analysis of the time series based on the ratio indicators of liquidity and profitability of the 10 largest banks doing business in the Republic of Serbia for the period between 2010 and 2017. In this research we used data from quarterly reports issued by the National Bank of Serbia and the selection criteria for banks was the amount of total net assets. As the percentage of participating banks' share is $77.1 \%$ of the total net assets of all banks operating in the Republic of Serbia, the values obtained approximate the performance of the entire banking system to a very good extent. The objective of this paper is to interpret these indicators in the aim of supporting the decision-making process concerning the credit-based and other finance-based relationships with clients so as to demonstrate whether monitoring of monetary authorities needs to be raised to a higher level, assuming that in the observed period the banking system of the Republic of Serbia was stable.
\end{abstract}

Keywords: bank liquidity, bank profitability, banking system, Republic of Serbia, decisionmaking, assets, monetary policies

JEL:G21

UDC: 336.71(497.11)"2010/2017"

\section{COBISS.SR-ID 277959948}




\section{LITERATURE REVIEW}

In order to better understand successfulness of one or any business, banking sector experts, mathematicians and economists have developed and created a number of indicators (Kenchington et al, 2019). As the nature of the operating methods of banks differs fundamentally from the business of companies in the nonfinancial sector, the financial statements differ as well, and their structure and content must reflect all the specifics of banking operations (Hadzic, 2009). The ratio indicators are calculated as a meaningful relationship between the positions in the financial statements and in order to analyse the performance of banks' operations they must be adjusted to the specificities of the financial statements of the banking sector. Ratio is the index by which one variable is measured in relation to the other variable and is usually calculated as a percentage or rate (Dimic et al, 2017). The nature of the banking operating methods consists in collecting cash from financially beneficial business entities and lending that money to deficient economic entities (Berger et al, 2017). All economic entities can be found on both the surplus and deficit side of the story - the population, companies and the state. As the deposit is paid by the bank, the bank pays the deposit interest rate and charges the active interest rate on the issued placements, the bank generates the largest part of the profit through the difference between the active and interest rate (Salem et al, 2012). The banking system constitutes a special part (a subsystem) of the overall economic system that enables the comprehensiveness of all social relations in which the financial mechanisms in production, distribution, exchange and consumption are developed and created (Andjelic et al, 2017). Banks have large amounts of money and their business is under constant and detailed monitoring by regulatory authorities (Mishkin, 2012). In this respect, they have a legal obligation to report on their daily work, and in order to retain the license, banks must provide the necessary level of capital adequacy and liquidity, as well as respond to all requests made by the National Bank of Serbia.

\section{RESEARCH PROBLEM, OBJECTIVE AND METHODOLOGY}

Banks are obliged to issue financial statements for the sake of annual transparency and submit them to the National Bank of Serbia for review and verification (Cogoljevic, 2018). Such certified reports represent official indicators of the state of financial stability, i.e. the assets and sources of the company on the given day (balance sheet), as well as the cash inflow and outflow, i.e. expenditures, revenues and results (profit and loss statement). The subject of this research is a comparative analysis of the time series of publicly issued regular annual reports of 10 banks operating in the Republic of Serbia - ratios of liquidity and profitability indicators were used to make the best possible comparison of the results obtained. According to the Report for the 4th quarter of the National Bank of Serbia, the percentage of participating banks' share is $77.1 \%$ of the total net assets of all banks operating in the Republic of Serbia, hence the values obtained approximate the performance of the entire banking system to a very good extent. The objective of the research is to calculate and interpret the aforementioned indicators and planned balance sheet positions observed through the prism of commercial banks with the purpose of supporting the decision-making process in entering into credit agreements and other financial relations with clients. The general hypothesis is that the banking sector was stable in the period between 2010 and 2017, alongside with two sub-hypotheses.

- In the long run, assets have the growth with the highest share in total net assets.

- The monitoring of the creditworthiness of current and potential clients in banks in the Republic of Serbia needs to be raised to a higher level. 


\section{EMPIRICAL ANALYSIS ON THE BASIS OF THE CURRENT STATE IN THE REPUBLIC OF SERBIA}

In this part of the paper, a graphical image with comments on calculated ratios of indicators is given. A specific chart is related to a specific ratio indicator and it displays the value of a specific indicator in the participating banks using a time series analysis for the period 2010 - 2017. In addition to individual values of ratio indicators of the 10 largest banks as per the amount of assets, their average value is also shown in order to better understand the performance dynamics of these banks. According to the report for the $4^{\text {th }}$ quarter of the National Bank of Serbia, the ten largest banks in the Republic of Serbia according to the above criterion are:

- Banca Intesa JSC - Belgrade

- Komercijalna banka JSC - Belgrade

- Unicredit Bank Srbija JSC - Belgrade

- Raiffeisen Banka JSC - Belgrade

- Societe Generale banka Srbija JSC - Belgrade

- Agroindustrijska komercijalna banka AIK banka JSC - Belgrade

- Eurobank JSC - Belgrade

- Erste Bank JSC - Novi Sad

- Banka Postanska stedionica JSC - Belgrade

- Vojvođanska banka JSC - Novi Sad

\section{DYNAMICS OF LIQUIDITY INDICATORS}

We obtained the first bank liquidity indicator by putting cash, short-term effects and total assets in relation (Vesic et al, 2018). As we can see in Chart no. 1 - in the observed period, the share of cash and short-term effects in total assets is on average at $15 \%$ to $30 \%$. Half of the banks we surveyed have these values above the average. The value of this indicator, which, from the aspect of liquidity, is at first glance a bad sign since the bank has smaller amounts of cash. The reason for this decline may be that banks have more funds invested based on which they earn more income, which is a preferred option for banks, but also because of the lower amount of cash due to the lack of collected deposits or their withdrawal.

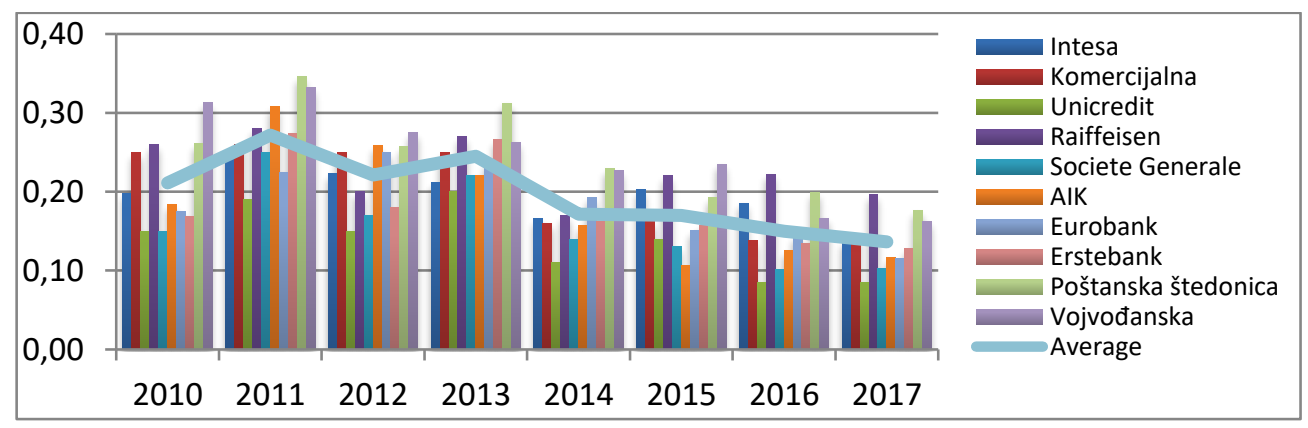

Chart 1. The share of cash and short-term effects in total assets

Source: Calculations by the authors based on the data obtained from the National Bank of Serbia 
The second liquidity indicator is obtained by dividing cash and short-term effects by deposits (Vesic et al, 2017). The results are shown on the Chart no. 2. Its average value dynamics follows the average value dynamics of the first liquidity indicator. The average value of the share of cash and short-term effects in bank deposits in the observed period ranged from $20 \%$ to $40 \%$. Based on the same dynamics of the first and second indicators, we see that there was no deposit decline, and that, consequently, the decrease in cash was not the result of a decrease in deposits or their withdrawal by depositors

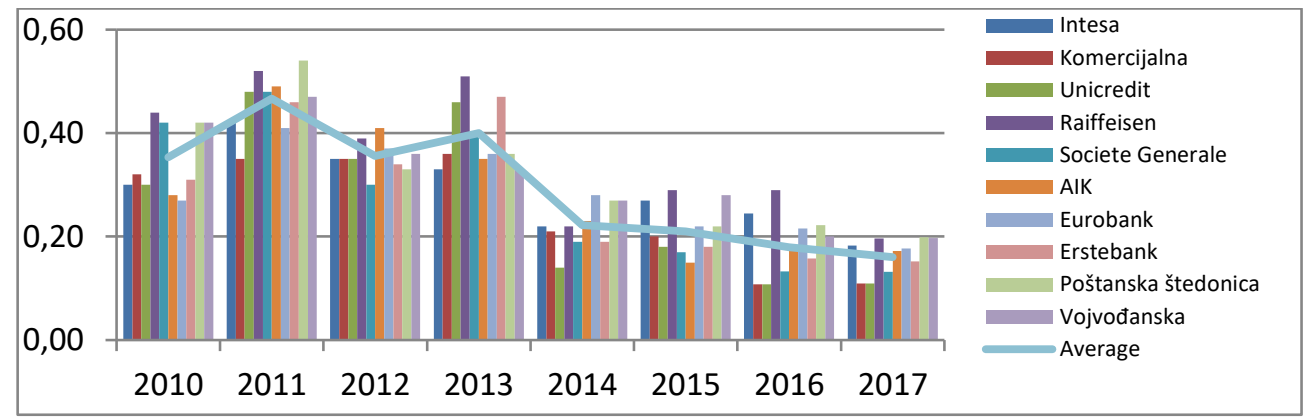

Chart 2. The share of cash and short-term effects in bank deposits

Source: Calculations by the authors based on the data obtained from the National Bank of Serbia

\section{Dynamics of the profitability indicator}

Return on Assets (ROA) represents the ratio of net profit and average total assets (Vukosavljevic et al, 2016). The indicator is displayed in Chart no. 3. The return on assets in the observed period is on average up to $1 \%$, but during the period it declined until 2015, when it started to increase again. This indicator shows that mostly foreign banks are above the average. When it comes to domestic banks, AIK Bank JSC Belgrade and Postanska stedionica JSC Belgrade had values above average up until 2013.

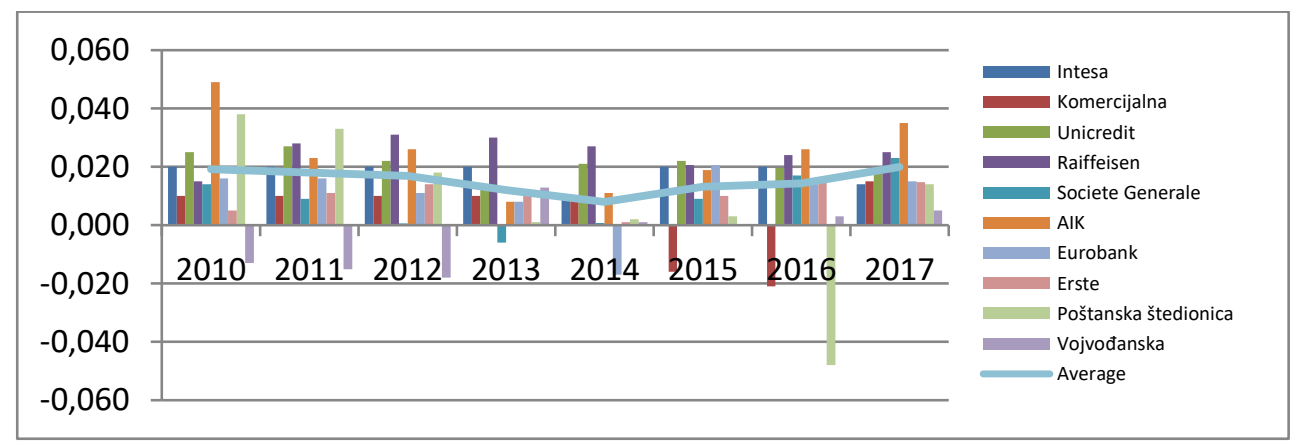

Chart 3. Return on assets

Source: Calculations by the authors based on the data obtained from the National Bank of Serbia

Return on Equity (ROE) represents the ratio of net profit and share capital and monitors the dynamics of return on assets (Zimonjić et al, 2018). The average value of the indicators from $8.6 \%$ in 2010, decreased until 2014 when it reached a minimum value of $3.7 \%$ and in 2015 
improved to $4.8 \%$. Approximately $60 \%$ of the participating banks had an above average ROE, with more foreign banks having results above average. In the group of 10 banks presented, each year one bank had losses. Not including the banks shown on the Chart, four of them - Pireus, KBM, Telenor and Alpha Bank had a loss in 4 out of 5 observed years. The largest "loser" of the observed period is the Postanska stedionica Bank JSC Belgrade in 2016, whose loss also reflected on (non)return on equity.

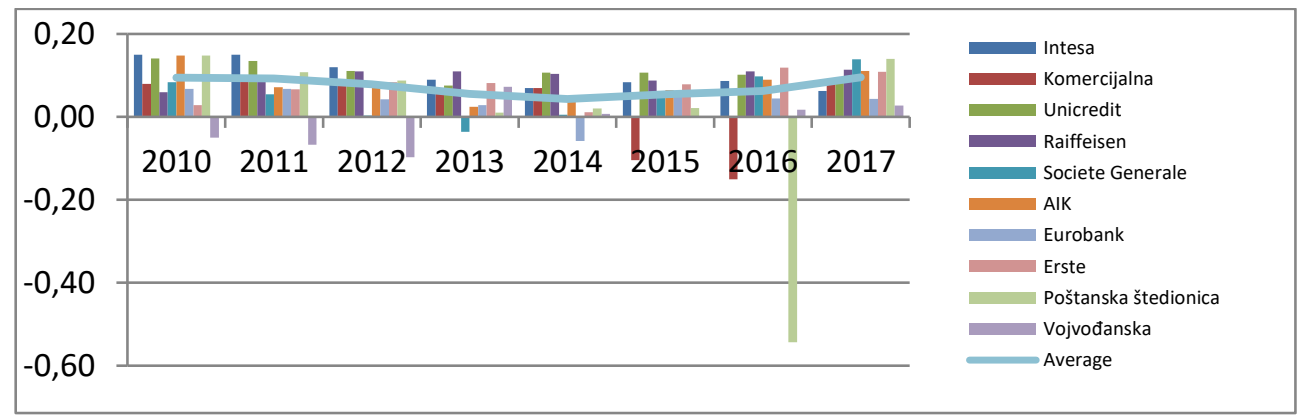

Chart 4. Return on equity

Source: Calculations by the authors based on the data obtained from the National Bank of Serbia

Return on Assets (ROA) and Return on Equity (ROE) reflect the profitability of the banking sector (Lukic et al, 2015). Since the link between equity and assets for all banks is rather stable and of the approximately same ratio, both ROA and ROE have similar movements, and by 2013 they point to profitable operations of banks. The rule is that if the efficiency of the bank's operations decreases, i.e. if the income-generating on assets is reduced (ROA decreases), the bank is then forced to take more risk through borrowing in order to achieve the planned return on equity (ROE), which is actually expected by shareholders (Ristanovic, 2017). The growing risk of bank operations was covered by capital assets. This endangered liquidity, so many banks were forced to recapitalize in order to maintain the obligatory level of capital adequacy. This also reflected negatively on profitability because capital increased, the cost of reservations rose, and profit was reduced.

\section{CONCLUSION}

With the outbreak of the global financial crisis, the central banks, along with commercial banks, continued to work to mitigate the effects on the banking and financial sector (Schiereck, 2016). During the crisis, having a conservative policy designed by the National Bank of Serbia, the banking sector was sufficiently resistant to handle all negative and crisis-induced consequences. In the period covered by the analysis, changes in the structure of the banking sector happened. There was a decrease in the number of banks and a decrease in the number of employees in the banking sector, and the amount of total net assets reported an increase. The amount of capital available to the banking sector grew and the dominant share in the total capital was owned by foreign-owned banks. After calculating the ratio indicators, we get an insight into the financial performance of banks in our banking sector (Doojav, 2018). From the first group of ratio indicators we see that the amount of cash that the banks have in disposal is decreasing, but banks still have sufficient amounts of cash in order not to jeopardize their liquidity. On the other hand, less liquid assets mean less cost on the basis of their holding because they generate revenues. By day-to-day innovations in the banking sector, banks are 
trying to improve their productivity, and as the ultimate effect their profitability as well since the primary motive when it comes to banks is to make the highest possible profit. Innovation is an effective method to accelerate growth and profitability in service companies, associated with new methods of value creation for both customers and companies (Fereydoon et al, 2018). The problem in the operations of banks occurs when they need to collect loans because, due to slower economic activity, clients are less and less able to fully and timely settle their obligations. Due to the high costs of unsecured loans, the banks' profits were halved, and some of the banks suffered losses. Solving this problem would need to include a more restrictive policy when approving loans and a better monitoring of the creditworthiness of current and potential clients.

\section{REFERENCES}

[1] Andjelic S., Vesic T. (2017). The importance of financial analysis for business decision making. Finance, banking and insurance - Book of proceedings from The Sixth International Scientific Conference „Employment, Education and Entrepreneurship“. Belgrade: Faculty of Business Economy and Entrepreneurship: pp. 9-25.

[2] Berger A., Bouwman C., Kick T., Schaeck, K. (2017). Bank risk taking and liquidity creation following regulatory interventions and capital support, Journal of Financial Intermediation, Forthcoming, 26 (1): pp. 115-141.

[3] Cogoljevic M., Vesic T., Dimitrijevic Lj., Cogoljevic V. (2018). The effect of marketing activities on the profitability of commercial banks in the Republic of Serbia, Filodiritto Editore - Proceedings, New business tendencies: pp. 37-44.

[4] Dimic M., Barjaktarovic L. (2017). Vlasnička transformacija bankarskog sektora u zemljama jugoistočne Evrope. Bankarstvo, 46(1): pp. 84-103.

[5] Doojav G, Batmunkh U. (2018). Monetary and macroprudential policy in a commodity exporting economy: A structural model analysis. Central Bank Review, Vol. 18, Issue 3: pp. 107-128.

[6] Fereydoon O, Jorfi A, Jorfi F. (2018). Study of the Relationship Between Entrepreneurial Services and Competitive Benefits of the Staff of Ahwaz University of Medical Sciences with the Mediator Role of Interactive and Supportive Innovation. International Review, No. 1/2-2018: pp. 60- 72

[7] Hadzic M. (2009). Bankarstvo, Univerzitet Singidunum.

[8] Kenchington D., Chi Wan H., Yüksel Z. (2019). Gross profitability and mutual fund performance, Journal of Banking \& Finance, Vol. 104: pp. 31-49.

[9] Kvartalni izveštaji 2010-2017, Narodna banka Srbije, downloaded 15.01.2019. from site https://www.nbs.rs/internet/latinica/55/55_4/index.html.

[10]Lukic Lj., Trsic M. (2015). Upravljanje rizicima i prinosima u bankama. Trendovi u poslovanju, 1(5): pp. 29-40.

[11] Mishkin F., Eakins, S. (2012). Financial markets and institution -7 th edition. Pearson Education, Boston.

[12] Ristanovic V. (2017). ROA i ROE u bankarskom sektoru Srbije, Ekonomske analize. Downloaded 10.12.2017. from site http://www.ekonomskeanalize. com/index.php/roa-iroe-u-bankarskom-sektoru-srbije-roa-and-roe-in-serbain-banking-sector.

[13] Salem M., Baidoun S., Walsh G. (2018). Factors affecting Palestinian customers' use of online banking services, Factors affecting Palestinian customers' use of online banking services, International Journal of Bank Marketing, Vol. 37, Issue 2, pp: 426 - 451. 
[14] Schiereck D., Florian K., Kolaric S. (2016). Brexit: (Not) another Lehman moment for banks? Finance Research Letters, Vol. 19: pp. 291-297.

[15] Vesic T., Petronijevic J., Trends in profitability of banks in Serbia through rational analysis, Finance and banking in sector industry - Book of proceeding from Seventh international Scientific Conference „Employment, Education and Entrepreneurship“. Belgrade: Faculty of Business Economy and Entrepreneurship: pp. 138-155.

[16] Vesic T., Radic N. (2018). Foreign banks - drivers of efficient development or yet another problem? Book of proceeding for Sixth International Conference FINIZ, Singidunum University: pp. 56-62.

[17] Vukosavljevic De., Vukosavljevic Da., Jelic G. (2016). The increasing importance of effective risk management in banking - findings from Serbia, International Review, 12/2016: pp. 101-108.

[18] Zimonjić S., Gavrilović M., Roganović M., (2018) Metode procene vrednosti akcija i kreiranje vrednosti za akcionare, Trendovi u poslovanju, 1(11): pp. 39-49.

\section{Article history:}

- Received 30 March 2019

- Accepted 15 May 2019 